\title{
PENGARUH KEJELASAN TUJUAN ANGGARAN DAN PARTISIPASI PENYUSUNAN ANGGARAN TERHADAP AKUNTABILITAS KINERJA INSTANSI PEMERINTAH (Studi Empiris Pada Instansi Pemerintah Kota Bengkulu)
}

\author{
Melly Susanti \\ Husaini \\ Isma Coryanata \\ mellysusanti131@ymail.com
}

Fakultas Ekonomi dan Bisnis Universitas Bengkulu

\begin{abstract}
This study aims to examine the influence of budget goal clarity and budget drafting participation on performance accountability of government institutions in Bengkulu city. This study is a descriptive research with purposive sampling technique. The subjects of this study were 136 officers of echelon III (Division Head/Sub-division Head/Secretary) and echelon IV (Chief Sub-division/Chief Section) of civil servants in government institutions in Bengkulu city. Data analysis technique used in this study was multiple linear regression test. The results of this study showed that: (1) Budget goal clarity influences positively and significantly on performance accountability of government institutions in Bengkulu city. (2) Budget drafting participation influences positively and significantly on performance accountability of government institutions in Bengkulu city. These results indicate that the higher budget target clarity and participation in budget drafting, the higher performance accountability will be.
\end{abstract}

Keywords: Budget Goal Clarity, Budget Drafting Participation, Performance Accountability.

\section{PENDAHULUAN}

\section{Latar Belakang}

Akuntabilitas kinerja instansi pemerintah adalah perwujudan kewajiban suatu instansi pemerintah untuk mempertanggungjawabkan keberhasilan atau kegagalan pelaksanaan program dan kegiatan yang telah diamanatkan para memangku kepentingan dalam rangka mencapai misi organisasi secara terukur dengan tujuan/target kinerja yang telah ditetapkan melalui laporan kinerja instansi pemerintah yang disusun secara periodik.

Terkait akuntabilitas kinerja, data menunjukkan bahwa Pemerintah Daerah Kota Bengkulu mengalami penurunan opini dari tahun 2012 hingga 2015, dari hasil 
Pemeriksaan Hasil Laporan Keuangan Pemerintah Daerah (LPH LKPD) oleh BPK RI perwakilan Provinsi Bengkulu. Dalam meningkatkan akuntabilitas kinerja pemerintah harus memperhatikan beberapa hal antara lain; partisipasi penyusunan anggaran dan kejelasan tujuan anggaran. Partisipasi penyusunan anggaran dan kejelasan tujuan anggaran yang baik maka akan tercapainya akuntabilitas kinerja instansi pemerintah yang baik. Tercapainya akuntabilitas kinerja instansi pemerintah akan menentukan kualitas atau kinerja dari pemerintah daerah.

Mardiasmo (2002) yang menyatakan wujud dari penyelenggaraan otonomi daerah adalah manfaat sumber daya yang dilakukan secara ekonomis, efisien, efektif, adil dan merata untuk mencapai akuntabilitas publik. Dari uraian diatas, maka peneliti akan menguji tentang "Pengaruh Kejelasan Tujuan Anggaran dan Partisipasi Penyusunan Anggaran Terhadap Akuntabilitas Kinerja Pada Instansi Pemerintah di Kota Bengkulu". Dengan adanya kejelasan tujuan anggaran dan partisipasi penyusunan anggaran maka setiap tahun akan dapat diukur seberapa jauh tingkat pencapaian atas hasil kinerja yang telah dilakukan yang dapat dipertanggung jawabkan pemerintah Kota Bengkulu kepada masyarakat.

\section{METODE PENELITIAN}

1. Jenis Penelitian

Penelitian ini merupakan penelitian deskriptif. Penelitian deskriptif merupakan penelitian terhadap masalah-masalah berupa fakta saat ini dari suatu populasi. Metode pengambilan sampel yaitu purpossive sampling. Variabel pada dasarnya adalah segala sesuatu yang dapat diberi berbagai macam nilai (Indriantoro dan Supomo, 2002). Variabel yang menghubungkan variabel satu dengan variabel lainnya dalam penelitian ini dapat dibedakan menjadi dua variabel yaitu variabel independen dan Variabel dependen. Variabel independen adalah kejelasan tujuan anggaran dan partisipasi penyusunan anggaran sementara variabel dependennya adalah akuntabilitas kinerja instansi pemerintah

2. Subjek Penelitian

Subjek dalam Penelitian ini adalah Aperatur Sipil Negri (ASN) di SKPD Pemerintah Kota Bengkulu yang terdiri dari sebagai berikut.

a. Sekretariat Daerah Kota Bengkulu.

b. Dinas-dinas Daerah sebagai unsur pelaksanaan Pemerintah Kota Bengkulu.

c. Badan dan lembaga teknis di lingkungan Kota Bengkulu sebagai unsur penunjang.

d. Inspektorat Kota Bengkulu sebagai unsur pengawas penyelenggaraan pemerintah daerah.

Subjek dalam penelitian penelitian ini dipilih berdasarkan kriteria: pejabat eselon III (Sekretaris/kabid/Kabag) dan pejabat eselon IV (Kasubid/Kasubag/Kasi). Alasan 
pemilihan sampel tersebut adalah telah memahami tugas dan fungsi pokok, dan dianggap memiliki kompetensi untuk memberikan informasi yang dibutuhkan.

3. Teknik Pengumpulan Data

Teknik yang digunakan dalam pengumpulan data penelitian ini adalah teknik non tes. Teknik non tes dilakukan dengan menyebarkan instrumen penelitian berupa kuesioner yang berisi pertanyaan-pertanyaan terkait variabel penelitian, yaitu: kejelasan tujuan anggaran, partisipasi penyusunan anggaran,dan akuntabilitas kinerja.

\section{Metode Pengumpulan Data}

a. Alat Pengumpulan Data

Jenis data yang digunakan dalam penelitian ini berupa data primer, yaitu data yang diperoleh secara langsung dari responden penelitian (staf instansi pemerintah Kota Bengkulu). Alat pengumpulan data dalam penelitian adalah kuesioner yang disusun berdasarkan definisi opersional. Kriteria pilihan jawaban dalam kuesioner menggunakan skala linkert dengan skor interval 1 sampai 5 . Kriteria pilihan jawaban responden, yaitu: (1) Sangat Tidak Setuju, (2) Tidak Setuju, (3) Cukup Setuju, (4) Setuju, dan (5) Sangat Setuju.

Alat pengumpulan data terdiri dari: (1) kuesioner untuk mengukur akuntabilitas kinerja yang terdiri dari 12 item pertanyaan. (2) Kuesioner untuk mengukur kejelasan tujuan anggaran yang terdiri dari 6 item pertanyaan. (3) Kuesioner untuk mengukur partisipasi penyusunan anggaran yang terdiri dari 6 item pertanyaan.

b. Prosedur Pengumpulan Data

Pengumpulan data dalam penelitian ini dilakukan dengan menyebarkan kuesioner kepada responden yaitu staf di Instansi Pemerintah Kota Bengkulu. Penyebaran dilakukan dengan cara memberikan kuesioner secara langsung dan menitipkan kepada responden dan diambil setelah satu minggu. Setelah kuesioner diisi oleh responden selanjutnya data ditabulasi berdasarkan masing-masing variabel penelitian.

\section{Metode Analisis Data}

Metode analisis data dalam penelitian ini terdiri dari dua, yaitu: analisis deskriptif dan analisis statistik infrensial. Secara rinci diuraikan sebagai berikut.

a. Analisis Statisik Deskriptif

Analisis deskriptif dalam penelitian ini bertujuan untuk mendeskripsikan tanggapan responden terhadap variabel penelitian, yaitu: akuntabilitas kinerja, kejelasan sasaran anggaran, dan partisipasi penyusunan anggaran. Hasil pengkuran persepsi/tanggapan responden diinterprestasikan berdasarkan interval pengukuran. Interval pengukuran berdasarkan skala linkert dengan interval skor 1 
sampai 5. Adapun penentuan interval kelas menggunakan rumus sebagai beriku (Nugroho, 2012: 23 ).

lebar kelas $=($ nilai terbesar-nilai terkecil $) / \mathrm{jumlah}$ kelas

Berdasarkan rumus diatas maka lebar kelas intervalnya adalah $(5-1 / 5)=0,8$. Skala rata-rata tanggapan responden di interprestasikan sebagai berikut.

\begin{tabular}{|l|l|l|}
\hline $1,00-1,80$ & $:$ & Sangat Rendah, Sangat Tidak Baik \\
\hline $1,81-2,60$ & $:$ & Rendah, Tidak Baik \\
\hline $2,61-3,40$ & $:$ & Sedang, Cukup \\
\hline $3,41-4,20$ & $:$ & Tinggi, Baik \\
\hline $4,21-5,00$ & $:$ & Sangat Tingi, Sangat Baik \\
\hline
\end{tabular}

\section{b. Analisis Statistik Infrensial}

Analisis data statistik infrensial terdiri dari beberapa tahapan, (1) uji kualitas data, (2) uji asumsi klasik, (3) analisis regresi berganda, (4) pengujian hipotesis.

\section{1) Pengujian Kualitas Data}

\section{a) Uji Validitas}

Validitas dapat dilakukan dengan mengkorelasikan antar skor item instrumen dengan skor total seluruh item pertanyaan. Batas minimum dianggap memenuhi syarat validitas apabila $r=0,3$. Jadi untuk memenuhi syarat validitas, maka butir pertanyaan atau pernyataan dalam penelitian harus memiliki koefisien korelasi $(r) \geq 0,3$. Apabila korelasi antara butir skor dengan skor total $(r)<0,3$ maka butir pertanyaan atau pernyataan dalam instrumen tersebut dinyatakan tidak valid. Pengujian validasi dilakukan dengan menggunakan bantuan sofware SPSS 17.00.

\section{b) Uji Reliabilitas}

Variabel dikatakan reliabel jika nilai Cronbach Alpha $>0,6$.

\section{2) Uji Asumsi Klasik}

a) Uji Normalitas

Metode yang digunakan adalah dengan menggunakan statistik Kolmogorov-Smirnov berbantuan program SPSS 17.00 For Windows dengan menggunakan taraf signifikan 0,05 . Kriteria yang digunakan dalam tes ini adalah dengan membandingkan antara tingkat signifikansi yang didapat dengan tingkat alpha yang digunakan, dimana data tersebut dikatakan berdistribusi normal bila sig >alpha (Ghozali, 2012:165) 
b) Uji Heteroskedastisitas

Uji heterokedastisitas dilakukan untuk mengetahui bahwa pada model regresi terjadi ketidaksamaan varian. Untuk mendeteksi ada atau tidaknya heterokedastisitas digunakan model glejser. Model ini dilakukan dengan meregresikan nilai absolute dengan variabel bebas. Ada tidaknya heteroskedastisitas dapat diketahui dengan melihat tingkat signifikansi terhadap

$\alpha=0,05$. Jika tidak ada satupun variabel bebas yang berpengaruh signifikan terhadap variabel terikat (nilai absolute ei), maka tidak ada heterokedastisitas (Ghozali, 2012:143).

\section{3) Analisis Regresi Berganda}

Analisis regresi digunakan untuk mengetahui besarnya pengaruh kejelasan Tujuananggaran dan partisipsi penyusunan anggaran terhadap akuntabilitas kinerja pada pemerintah Kota Bengkulu. Persamaan matematis untuk hubungan yang dihipotesiskan dapat dirumuskan sebagai berikut:

$\mathrm{Y}=\mathrm{a}+\mathrm{b}_{1} \mathrm{X}_{1}+\mathrm{b}_{2} \mathrm{X}_{2}$

Keterangan :

$\mathrm{Y}=$ Akuntabilitas kineja instansi pemerintah

$\mathrm{a}=$ (konstanta)

$\mathrm{b}_{1}=$ Koefisien regresi kejelasan tujuan Anggaran

$\mathrm{b}_{2}=$ Koefisien regresi partisipasi penyusunan anggaran

$\mathrm{X}_{1}=$ Kejelasan Tujuan Anggaran

$\mathrm{X}_{2}=$ Partisipasi Penyusunan Anggaran

\section{4) Pengujian Hipotesis}

a) Uji F Statistik

Uji statistik $\mathrm{F}$ pada dasarnya menunjukkan apakah semua variabel bebas yang dimasukkan dalam model mempunyai pengaruh secara bersama-sama terhadap variabel terikat (Ghozali, 2012:98). Apabila $\mathrm{p}$ value menunjukkan $\alpha<0,05$ maka model yang digunakan layak.

b) Pengujian Satistik Parsial (Uji t)

Uji statistik t pada dasarnya menunjukkan seberapa jauh pengaruh satu variabel penjelas/independen secara individual dengan menerangkan variasi variabel dependen (Ghozali, 2012:98). Uji t dapat dilakukan dengan melihat nilai probabilitas signifikansi t masing-masing variabel yang terdapat pada output hasil regresi menggunakan SPSS 17.00 for windows. Jika hipotesis masing-masing variabel bebas 
diterima apabila $\alpha<0,05$, sebaliknya jika masing-masing variabel bebas $\alpha>0,05$ maka hipotesis ditolak.

c) Uji Koefisien Determinasi $\left(\mathrm{R}^{2}\right)$

Ghozali (2012:97) menyatakan bahwa koefisien determinasi $\left(\mathrm{R}^{2}\right)$ pada intinya mengukur seberapa jauh kemampuan model dalam menerangkan variabel terikat. $\mathrm{R}^{2}$ dapat diinterpretasikan bahwa sebesar $\left(\mathrm{R}^{2} \times 100 \%\right)$ variasi dari variabel terikat mampu dijelaskan oleh variabel bebas, sedangkan sisanya $\left(100 \%-\mathrm{R}^{2} \mathrm{x} 100 \%\right)$ dipengaruhi oleh faktor lain di luar model. Koefisien determinasi $\left(\mathrm{R}^{2}\right)$ digunakan untuk mengukur seberapa jauh kemampuan model dalam menjelaskan variasi variabel indevenden. Nilai koefisien determinasi adalah antara nol sampai dengan satu. Apabila nilai $\mathrm{R}^{2}$ semakin kecil, maka kemampuan variabel independen dalam menjelaskan variasi variabel dependen semakin rendah. Apabila nilai $\mathrm{R}^{2}$ mendekati satu, maka variabel indevenden memberikan hampir semua informasi yang dibutuhkan untuk memprediksi variasi variabel dependen.

\section{HASIL DAN PEMBAHASAN}

\section{Deskripsi Pengumpulan Data Hasil Penelitian}

Pengumpulan data dalam penelitian ini dilakukan dengan cara menyebarkan kuesioner penelitian kepada responden Waktu yang dibutuhkan dalam penyebaran kuesioner pada penelitian ini selama satu minggu, yaitu dari tanggal 29 Februari 2016 sampai 4 Maret 2016. Kuesioner disebarkan sebanyak 200 buah yang disesuaikan dengan jumlah Instansi di Pemerintah Kota Bengkulu sebagai tujuan penelitian yaitu sebanyak 24 instansi. Jumlah kuesioner yang disebarkan juga didasarkan informasi dari instansi terkait staf yang dapat mengisi kuesioner seperti Tabel 1 berikut:

Tabel 1. Data Distribusi Kuesioner

\begin{tabular}{|l|l|l|}
\hline No & Gambaran Kuesioner & Jumlah \\
\hline 1 & $\begin{array}{l}\text { Kuesioner yang disebar ke } \\
\text { responden }\end{array}$ & 200 \\
\hline 2 & $\begin{array}{l}\text { Kuesioner yang tidak } \\
\text { kembali }\end{array}$ & 8 \\
\hline 3 & Kuisioner yang rusak & 2 \\
\hline 4 & $\begin{array}{l}\text { Kuesioner yang kembali } \\
\text { tetapi tidak lengkap }\end{array}$ & 54 \\
\hline 5 & $\begin{array}{l}\text { Kuesioner yang memenuhi } \\
\text { kriteria }\end{array}$ & 136 \\
\hline
\end{tabular}




\section{Gambaran Umum Responden}

Responden dalam penelitian ini berasal dari Anggota Sipil Negeri ditingkat Eselon III (Kabid/Kabag/Sekretaris) dan ditingkat Eselon tingkat IV (Kasubid/Kasubag/Kasubdis/Kasi) di instansi-intansi pemerintah Kota Bengkulu, yaitu sebanyak 136 orang. Karakteristik responden dalam penelitian seeperti pada tabel berikut.

\begin{tabular}{|c|c|c|c|}
\hline No & Kategori & $\begin{array}{l}\text { Jumlah } \\
\text { (orang) }\end{array}$ & Persentase (\%) \\
\hline \multirow[t]{2}{*}{1} & $\begin{array}{l}\text { Jenis Kelamin } \\
\text { a. Laki-laki } \\
\text { b. Perempuan }\end{array}$ & $\begin{array}{l}69 \\
67\end{array}$ & $\begin{array}{l}50,73 \\
49,27 \\
\end{array}$ \\
\hline & Total & 136 & 100 \\
\hline \multirow[t]{2}{*}{2} & $\begin{array}{l}\text { Umur } \\
\text { a. 20-40 Tahum } \\
\text { b. } 70 \text { Tahun }\end{array}$ & $\begin{array}{l}39 \\
97\end{array}$ & $\begin{array}{l}28,68 \\
71,32\end{array}$ \\
\hline & Total & 136 & 100 \\
\hline \multirow[t]{2}{*}{3} & $\begin{array}{l}\text { Pendidikan Terakhir } \\
\text { a. Diploma D3 } \\
\text { b. Sarjana (S1) } \\
\text { c. S2 } \\
\text { d. S3 }\end{array}$ & $\begin{array}{c}4 \\
101 \\
31 \\
0\end{array}$ & $\begin{array}{l}2,94 \\
74,26 \\
22,8\end{array}$ \\
\hline & Total & 136 & 100 \\
\hline \multirow[t]{2}{*}{4} & $\begin{array}{l}\text { Latar Belakang } \\
\text { Pendidikan } \\
\text { a. Akuntansi dan } \\
\text { manajemen } \\
\text { b. Teknik } \\
\text { c. Hukum dan Sosial } \\
\text { d. Lain-lain }\end{array}$ & $\begin{array}{c}34 \\
1 \\
58 \\
43\end{array}$ & $\begin{array}{l}25 \\
0,75 \\
42,64 \\
31,61\end{array}$ \\
\hline & Total & 136 & 100 \\
\hline \multirow[t]{2}{*}{5} & $\begin{array}{l}\text { Jabatan/Golongan } \\
\text { a. Golongan III } \\
\text { b. Golongan IV }\end{array}$ & $\begin{array}{l}43 \\
94\end{array}$ & $\begin{array}{l}31,62 \\
68,38\end{array}$ \\
\hline & Total & 136 & 100 \\
\hline \multirow[t]{2}{*}{6} & $\begin{array}{l}\text { Lama Bekerja } \\
\text { a. 1-5 Tahun } \\
\text { b. 6-10Tahum } \\
\text { c. 11-15 Tahum } \\
\text { d. 16-20 Tahum } \\
\text { e. }>21 \text { Tahun }\end{array}$ & $\begin{array}{l}43 \\
12 \\
13 \\
33 \\
35 \\
\end{array}$ & $\begin{array}{l}\begin{array}{l}31,6 \\
8,8 \\
9,6 \\
25,7\end{array} \quad 24,3 \\
\end{array}$ \\
\hline & Total & 136 & 100 \\
\hline
\end{tabular}

\section{Hasil penelitian}

a. Tanggapan responden terhadap akuntabilitas kinerja

Gambaran tanggapan responden terhadap setiap pernyataan dari variabel akuntabilitas kinerja seperti pada tabel di bawah ini.

Tabel 3. Distribusi Jawaban Responden Pada Akuntabilitas Kinerja

\begin{tabular}{|l|l|}
\hline \multicolumn{1}{|c|}{$\begin{array}{l}\text { Pernyataan Variabel } \\
\text { Akuntabilitas Kinerja (Y) }\end{array}$} & $\begin{array}{c}\text { Rata- } \\
\text { Rata }\end{array}$ \\
\hline $\begin{array}{l}\text { Lancarnya suatu kegiatan/program, lebih } \\
\text { diutamakan dibandingkan efisiensi penggunaan } \\
\text { sumber dana }\end{array}$ & 3,42 \\
\hline $\begin{array}{l}\text { Adanya keterkaitan yang sangat erat antara } \\
\text { pencapaian kinerja dengan program dan kebijakan. }\end{array}$ & 4,35 \\
\hline $\begin{array}{l}\text { Adanya kejelasan antara tujuan dan tujuan dari } \\
\text { suatu kegiatan/program yang akan dan sedang } \\
\text { dilaksanakan }\end{array}$ & 4,09 \\
\hline
\end{tabular}




\begin{tabular}{|l|l|}
\hline $\begin{array}{l}\text { Pengukuran kinerja dapat dilakukan dengan data } \\
\text { internal dan external. }\end{array}$ & 3,60 \\
\hline $\begin{array}{l}\text { Indikator kinerja perlu untuk mengukur } \\
\text { keberhasilan suatu kegiatan/program }\end{array}$ & 3,79 \\
\hline $\begin{array}{l}\text { Melakukan analisis anggaran terhadap } \\
\text { kegiatan/program merupakan bagian dari evaluasi } \\
\text { yang selalu dilakukan, setelah selesainya suatu } \\
\text { kegiatan/program untuk kepentingan pribadi adalah } \\
\text { hal biasa yang dilakukan. }\end{array}$ & 3,33 \\
\hline $\begin{array}{l}\text { Menggunakan fasilitas kegiatan/program untuk } \\
\text { kepentingan pribadi adalah hal biasa yang dilakukan }\end{array}$ & 3,77 \\
\hline $\begin{array}{l}\text { Selalu melakukan evaluasi kegiatan/program } \\
\text { berdasarkan standar-standar tertentu yang berlaku. }\end{array}$ & 3,80 \\
\hline $\begin{array}{l}\text { Setiap selesainya kegiatan/ program perlu dibuat } \\
\text { laporan ke atasan dan dipublikasikan ke masyarakat. }\end{array}$ & 3,24 \\
\hline $\begin{array}{l}\text { Saya lebih mengutamakan jelannya } \\
\text { kegiatan/program daripada hasil akhir yang } \\
\text { diperoleh masyarakat. }\end{array}$ & 3,25 \\
\hline $\begin{array}{l}\text { Saya selalu melakukan analisis kebijakan terhadap } \\
\text { kegiatan/program. }\end{array}$ & 3,89 \\
\hline $\begin{array}{l}\text { Saya selalu melakukan pengecekan terhadap } \\
\text { jalannya kegiatan/program. }\end{array}$ & 3,80 \\
\hline
\end{tabular}

b. Tanggapan responden terhadap kejelasan tujuan anggaran

Hasil analissi tanggapan responden terhadap kejelasan tujaun anggaran di Pemerintah Kota bengkulu pada Tabel 4 sebagai berikut.

Tabel 4.

Tanggapan pada Kejelasan Tujuan Anggaran

\begin{tabular}{|l|l|}
\hline \multicolumn{1}{|c|}{$\begin{array}{c}\text { Pernyataan Variabel } \\
\text { kejelasan tujuan anggaran }\end{array}$} & $\begin{array}{c}\text { Rata- } \\
\text { rata }\end{array}$ \\
\hline $\begin{array}{l}\text { Atasan membuat rincian tugas-tugas yang } \\
\text { harus dikerjakan oleh bawahan. }\end{array}$ & 3,79 \\
\hline $\begin{array}{l}\text { Atasan menyatakan kinerja bawahan dalam } \\
\text { bentuk pernyataan yang dapat diukur. }\end{array}$ & 3,60 \\
\hline $\begin{array}{l}\text { Atasan menetapkan standar/target } \\
\text { pencapaian program kegiatan. }\end{array}$ & 3,51 \\
\hline $\begin{array}{l}\text { Atasan menetapkan jangka waktu yang } \\
\text { diperlukan untuk menyelesaikan program } \\
\text { kegiatan yang telah direncankan. }\end{array}$ & 3,50 \\
\hline $\begin{array}{l}\text { Atasan selalu memperioritaskan program } \\
\text { kegiatan yang akan disusun. }\end{array}$ & 3,70 \\
\hline $\begin{array}{l}\text { Atasan menetapkan tujuan program kegiatan } \\
\text { berdasarkan tingkat prioritas dan pentingnya }\end{array}$ & 3,93 \\
\hline
\end{tabular}


c. Tanggapan responden terhadap partisipasi penyusunan anggaran Gambaran tanggapan responden terhadap setiap pernyataan dari variabel $p$ partisipasi penyusunan anggaranseperti pada Tabel 5 di bawah ini.

\section{Tabel 5}

Tanggapan Responden Variabel partisipasi penyusunan anggaran

\begin{tabular}{|l|l|}
\hline \multicolumn{1}{|c|}{$\begin{array}{c}\text { Pernyataan Variabel } \\
\text { Kinerja Kerja (Y) }\end{array}$} & \multicolumn{1}{|c|}{$\begin{array}{c}\text { Rata- } \\
\text { rata }\end{array}$} \\
\hline $\begin{array}{l}\text { Atasan selalu melibatkan bawahan dalam } \\
\text { penyusunan anggaran. }\end{array}$ & 3,81 \\
\hline $\begin{array}{l}\text { Atasan melakukan refisi/koreksi anggaran } \\
\text { dengan alasan yang sesuai aturan. }\end{array}$ & 3,92 \\
\hline $\begin{array}{l}\text { Atasan selalu mendiskusikan anggaran yang } \\
\text { akan disusun. }\end{array}$ & 3,94 \\
\hline $\begin{array}{l}\text { Usulan bawahan tercermin dalam usulan } \\
\text { final. }\end{array}$ & 3,66 \\
\hline $\begin{array}{l}\text { Atasan selalu menilai kontribusi bawahan } \\
\text { terhadap penyusunan anggaran. }\end{array}$ & 3,82 \\
\hline $\begin{array}{l}\text { Atasan selalu menerima usulan bawahan } \\
\text { pada saat penyusunan anggaran. }\end{array}$ & 3,70 \\
\hline
\end{tabular}

\section{Hasil Uji Hipotesis}

Pengujian hipotesis dilakukan untuk menjawab hipotesis yang telah disusun, yaitu melihat pengaruh variabel independen (kejelasan tujuan anggaran dan partisipasi penyusunan anggaran) terhadap variabel dependen (akuntabilitas kinerja). Pengujian hipotesis dilakukan dengan uji regresi linier berganda dengan tingkat kepercayan 95\%. Hasil uji regresi linier berganda menggunakan sofware SPSS 17.00 for windows secara lengkap dapat dilihat pada lampiran 6. Hasil uji statistik regresi linier berganda menggambarkan hubungan antara kejelasan tujuan anggaran dan partisipasi penyusunan anggaran terhadap akuntabilitas kinerja. Adapun hasil analisis regresi linier berganda ditunjukkan Tabel 6 sebagai berikut.

Tabel 6

Hasil uji regresi linier berganda

\begin{tabular}{|c|c|c|c|c|c|c|c|c|}
\hline & \multirow[t]{2}{*}{ Model } & \multicolumn{2}{|c|}{$\begin{array}{c}\text { Unstandardized } \\
\text { Coefficients }\end{array}$} & \multicolumn{2}{|c|}{ Hasil Uji t } & \multicolumn{2}{|c|}{ Hasil Uji F } & \multirow[t]{2}{*}{$\begin{array}{c}\mathrm{R} \\
\text { Square }\end{array}$} \\
\hline & & B & Std. Error & t-hitung & $\mathrm{Sig}$ & F-hitung & Sig & \\
\hline \multirow{3}{*}{1} & (Constant) & 16,84 & 2,331 & 7,224 &, 000 & \multirow[t]{3}{*}{7,22} & \multirow[t]{3}{*}{0,00} & \multirow[t]{3}{*}{0,512} \\
\hline & $\begin{array}{l}\text { Kejelasan Tujuan } \\
\text { Anggaran } \\
\end{array}$ & 0,385 & ,155 & 2,489 &, 014 & & & \\
\hline & \begin{tabular}{|l|} 
Partisipasi \\
Penyusunan Anggaran
\end{tabular} & 0,750 & , 190 & 3,950 &, 000 & & & \\
\hline
\end{tabular}


Tabel di atas menunjukkan bahwa persamaan model regresi yang diperoleh yaitu $Y$ $=16,84+0,38 X_{1}+0,75 X_{2}$. Persamaan ini menunjukkan bahwa penambahan kategori kejelasan tujuan anggaran akan meningkat akuntabiltas sebesar 0,38 dengan asumsi partisapasi penyusunan anggaran tetap. Sedangkan penambahan pada variabel partisipasi penyusunan anggaran akan meningkat akuntabiltas kinerja sebesar 0,750. Hasil uji regresi linier berganda akan dianalisis berdasarkan uji statistik F, uji parsial (uji t), dan uji kooefisien determinasi. Adapun analisis tersebut diuraiakan sebagai berikut.

\section{a. Uji F Statistik}

Analisis hasil uji statistik $\mathrm{F}$ dilakukan untuk melihat apakah semua variabel independen dalam model berpengaruh secara bersama-sama terhadap variabel dependen dan model regresi yang digunakan signifikan atau layak. Adapun kriteria pengujian adalah : jika nilai probabilitas (sig.) kurang dari $\alpha=0,05$, maka model layak digunakan. Berdasarkan hasil uji F diperoleh nilai singnifikasni sebesar 0,000 dan kurang dari $\alpha=0,05$. Hal ini menunjukkan pada tingkat kepercayaan $95 \%$ model dinyatakan signifikansi dan layak. Selain itu hasil ini juga menunjukkan adanya pengaruh secara bersama-sama kejelesaan tujuan dan partisipasi penyusunan anggaran terhadap akuntabilitas kinerja.

\section{b. Pengujian Satistik Parsial (Uji t )}

Hasil uji $\mathrm{t}$ digunakan untuk menentukan pengaruh masing-masing variabel independen terhadap variabel dependen. Hasil analisis uji t untuk menjawab hipotesis penelitian yang telah disusun. Adapun hipotesis yang diuji dalam penelitian ini adalah sebagai berikut:

\begin{tabular}{|l|l|}
$\mathrm{H}_{1}:$ & $\begin{array}{l}\text { Kejelasan tujuan anggaran berpengaruh positif dan signifikan terhadap } \\
\text { akuntabilitas kinerja }\end{array}$ \\
\hline $\mathrm{H}_{2}:$ & $\begin{array}{l}\text { Partisipasi penyusunan anggaran berpengaruh positif dan signifikan } \\
\text { terhadap akuntabilitas kinerja }\end{array}$ \\
\hline
\end{tabular}

Dengan kriteria pengujian: Jika nilai probabilitas (sig) kurang dari $\alpha=0,05$ atau nilai t-hitung lebih dari nilai $\mathrm{t}$-tabel dengan derajat bebas 135 dan $\alpha=0,05$ yaitu 1,97 maka hipotesis diterima. Hal ini sesuai dengan pendapat Ghozali (2012) yang menyebutkan hipotesis masing-masing variabel bebas diterima apabila kurang dari $\alpha=0,05$, sebaliknya jika lebih besar dari $\alpha=0,05$ maka hipotesis ditolak.

Adapun hasil uji t berdasarkan hasil analisis regresi berganda menunjukkan bahwa pada variabel kejelasan tujuan $t$-hitung sebesar 2,48 lebih dari $t_{\text {-tabel }}=1,97$ dengan nilai sig seebesar 0,014 kurang dari $\alpha=0,05$. Hal ini menunjukkan bahwa hipotesis diterima, sehingga kejelasan tujuan anggaran berpengaruh terhadap akuntabilitas kinerja. Selanjutnya partisipasi penyusunan anggaran juga mempunyai pengaruh positif terhadap akuntabilitas kinerja. Hal ini ditunjukkan dari hasil analisis nilai $t_{\text {hitung }}$ sebesar 3,95 lebih dari $t_{\text {tabel }}=1,97$ dengan signifikasni kurang dari $\alpha=0,05$. Sehingga semakin tinggi partisipasi penyusunan anggaran maka semakin tinggi akuntabilitas kinerja dalam suatu instansi pemerintah di Kota Bengkulu. 
Berdasarkan hasil uji regresi linier berganda maka hubungan dari setiap hipotesis dalam penelitian. Berdasarkan hasil analisis dapat dirangkumkan seperti pada Tabel 7 berikut:

\section{Tabel 7}

Hasil Analisis Hipotesis Penelitian

\begin{tabular}{|l|l|l|}
\hline \multicolumn{2}{|c|}{ Hipotesis Penelitian } & Hasil uji \\
\hline $\mathrm{H}_{1}$ & $\begin{array}{l}\text { Kejelasan tujuan anggaran berpengaruh positif dan } \\
\text { signifikan terhadap akuntabilitas kinerja }\end{array}$ & Diterima \\
\hline $\mathrm{H}_{2}$ & $\begin{array}{l}\text { Partisipasi penyusunan anggaran berpengaruh positif } \\
\text { dan signifikan terhadap akuntabilitas kinerja }\end{array}$ & Diterima \\
\hline
\end{tabular}

\section{c. Uji Koefisien Determinasi $\left(\mathbf{R}^{2}\right)$}

Hasil analisis uji regresi linier berganda menunjukkan bahwa nilai $R^{2}=0,512$, sehingga disimpulkan pengaruh variabel independen (kejelasan tujuan anggaran dan partisipasi penyusunan anggaran) terhadap variabel dependen (akuntabilitas kinerja) sebesar 51,20\%, sedangkan sisanya dipengaruhi oleh variabel lain. Hal ini sesuai dengan pendapat Ghozali (2012: 97) yang menyatakan bahwa koefisien determinasi $\left(\mathrm{R}^{2}\right)$ pada intinya mengukur seberapa jauh kemampuan model dalam menerangkan variabel terikat, sedangkan sisanya dipengaruhi oleh faktor lain di luar model.

\section{KESIMPULAN DAN SARAN}

\section{Kesimpulan}

Berdasarkan hasil dan pembahasan yang telah diuraikan, maka simpulan dari penelitian ini adalah sebagai berikut:

a. Kejelasan tujuan anggaran berpengaruh positif dan signifikan terhadap akuntabilitas kinerja di Instansi Pemerintah Kota Bengkulu. Hal ini menunjukkan semakin jelas tujuan anggaran bagi staf/pegawai di Instansi Pemerintah Kota Bengkulu maka semakin baik akuntabilitas kinerja yang dihasilkan.

b. Partisipasi penyusunan anggaran berpengaruh positif dan sigtnifikan terhadap akuntabilitas kinerja di Instansi Pemerintah Kota Bengkulu. Hal ini menunjukkan semakin tinggi partisipasi staf/pegawai dalam penyusunan anggaran maka semakin baik akuntabilitas kinerja.

\section{Implikasi}

Hasil penelitian diharapkan mempunyai implikasi terhadap pemerintahan Kota Bengkulu untuk meningkatkan akunbtabilitas kinerja. Hal dapat dilakukan dengan memberikan informasi secara rinci terkait kejelasan tujuan anggaran yang akan dilaksanakan kepada staf/pegawai sehingga dalam merealisasikan 
perogram/kegiatan pegawai mempunyai rencana. Selain itu, pemerintah Kota Bengkulu dapat mengikutsertakan staf/pegawai dalam penyusunan anggaran sehingga mengetahui secara rinci target yang harus dikerjakan dan direalisasi.

\section{Keterbatasan Penelitian}

Penelitian ini mempunyai beberapa keterbatasan. Adapun keterbatasan dalam penelitian ini adalah sebagai berikut:

a. Alat pengumpulan data dalam penelitian ini hanya terbatas pada kuesioner sehingga hanya berdasarkan penilaian responden saja.

b. Dalam pengumpulan data penulis memiliki keterbatasan waktu sehingga kuesioner tidak dapat diserahkan secara langsung kepada responden sehingga sebagian kuesioner dititip untuk kemudian diambil kembali.

\section{Saran}

Berdasarkan keterbatasan dalam penelitian ini, maka saran dapat disimpulkan sebagai berikut:

a. Penelitian selanjutnya dapat menambah alat pengumpulan data seperti wawancara, lembar observasi

b. Penelitian selanjutnya juga dapat menambahkan variabel lain penelitian yang secara teori dapat mempengaruhi akuntabilitas kinerja dan dapat memperluas subjek penelitian.

\section{DAFTAR PUSTAKA}

Ghozali, Imam. 2012. Aplikasi Analisis Multivariate dengan ProgramIBM SPSS 20. Semarang: Badan Penerbit Universitas Diponegoro.

Harian Bengkulu Ekspress. 2014. Laporan hasil pemeriksaan keuangan pemerintah Kota Bengkulu 13/06/2014. di akses di: http://bengkuluekspress.com/4kabupaten-raih-wtp/. 4 PEMDA WTP 4 PEMDA WDP.

Kepres RI. 2014. Pepres RI no 29tentang Sistem akuntabilitas kinerja instansi pemerintah

Mardiasmo. 2002a. Otonomi dan Manajemen Keuangan Daerah. Yogyakarta: Andi Peratama

Mardiasmo. 2002b. Akuntansi Sektor Publik. Edisi Pertama. Yogyakarta: Andi Peratama

Munawar, Gugus Irianto dan Nurkholis. (2006). Pengaruh Karakteristik Tujuan Anggaran Terhadap Perilaku, Sikap dan Kinerja Aparat Pemerintah Daerah di kabupaten Kupang.Simposium Nasional Akuntansi 9 Padang, 23-26 Agustus 2006.

Sugiyono, 2007. Metode Penelitian Bisnis.Bandung: Alfabet

Sekaran, Uma. 2006. Metodologi Penelitian Untuk Bisnis. Jakarta: Salemba Empat

Umar, Husein. 2004. Riset Pemasaran dan Perilaku Konsumen. Jakarta: PT. Gramedia Pustaka Utama. 
www.bengkulukota.go.id/berita-122_laporan-hasil-pemeriksaan-lhp-dan-laporankeuangan-pemeritah-kota-bengkulu.htm 